\title{
Physical activity and respiratory muscle strength in elderly: a systematic review
}

\section{Atividade física e força muscular respiratória de idosos: uma revisão sistemática}

\author{
Fabio Dutra Pereira ${ }^{[a]}$, Wagner Oliveira Batista ${ }^{[b]}$, Patrícia dos Santos Claro Fuly ${ }^{[c]}$, \\ Edmundo de Drummond Alves Junior ${ }^{[\mathrm{d}]}$, Elirez Bezerra da Silva ${ }^{[\mathrm{e}]}$
}

[a] Master Degree in Human Myology (Physiotherapy and Physical Education), coordinator of the InFocus Research Group (UCB-RJ), professor of Physiotherapy and Physical Education Courses, Rio de Janeiro, RJ - Brazil, e-mails: profabiodutra@gmail.com, profabiodutra@hotmail.com

[b] Master Degree in Health Care Sciences (Physical Education), researcher of the Physical Activity and Aging Research Group from Universidade Federal Fluminense (UFF), Niterói, RJ - Brazil, e-mail: wagnerbatista1@gmail.com

[c] Doctor Degree in Nursing, professor of Health Care Sciences Postgraduate Program at Universidade Federal Fluminense (UFF), researcher of the Gerontological Nursing Research and Study Center (UFF), Niterói, RJ - Brazil, e-mail: patriciafuly@enf.uff.br

[d] Doctor Degree in Physical Education, professor of Health Care Sciences Postgraduate Program at Universidade Federal Fluminense (UFF), researcher of the Physical Activity and Aging Research Group (UFF), Niterói, RJ - Brazil, e-mail: edmundodrummond@uol.com.br

[e] Doctor Degree in Physical Education, professor of the Exercise and Sport Sciences Stricto Sensu Postgraduate program, Physiotherapy Course coordinator at Universidade Gama Filho (UGF), Rio de Janeiro, RJ - Brazil, e-mail: elirezsilva@ugf.br

\section{Abstract}

Introduction: The aging will inevitably bring some kind of functional decline in elderly, sarcopenia in this sense stands out because it damages the muscle function and extend also to the respiratory muscles. Objective: Systematically review studies that have sought to compare the strength of respiratory muscles between sedentary and physically active elderly in training programs nonspecific respiratory musculature. Materials and methods: From the descriptors motor activity, respiratory muscles and elderly, the databases LILACS, MedLine, Cochrane, PEDro, Scirus and Redalyc were consulted. Results: Of 1.263 experiments available in said databases, 12 were recovered and 6 were selected due they meet all the inclusion 
criteria and selection requirements. Conclusion: Physical activity programs offered by the selected studies led physically active elderly to have respiratory muscle strength statistically higher than the sedentary. However, this condition did not expressed itself as security to these elderly to present strength levels above of the minimum predictive of normality.

Keywords: Motor activity. Respiratory muscles. Elderly.

\section{Resumo}

Introdução: $O$ envelhecimento inevitavelmente trará algum tipo de declínio funcional ao idoso. Nesse sentido, a sarcopenia se destaca por acometer a função muscular e se estender também à musculatura respiratória. Objetivo: Revisar sistematicamente os estudos que buscaram comparar a força dos músculos respiratórios entre idosos sedentários e fisicamente ativos em programas de treinamento inespecíficos à musculatura respiratória. Materiais e métodos: A partir dos descritores atividade física, músculos respiratórios e idoso, foram consultadas as bases de dados LILACS, MedLine, Cochrane, PEDro, Scirus e Redalyc. Resultados: Dos 1.263 experimentos disponíveis nas referidas bases, 12 foram recuperados e 6 selecionados por atenderem totalmente aos critérios de inclusão e seleção estabelecidos. Conclusão: Os programas de atividade física propostos pelos estudos selecionados levaram os idosos fisicamente ativos a apresentarem força dos músculos respiratórios estatisticamente superior à dos sedentários. Ainda assim, essa força não foi necessariamente superior ao valor mínimo preditivo de normalidade.

Palavras-chave: Atividade física. Músculos respiratórios. Idoso.

\section{Introduction}

Due to the Brazilian demographic aging (1), it is important that public health policies of the country create strategies for social, cultural and economic inclusion not only for the elderly but also for their family members $(2,3)$ because the senescence includes biological, psychological and social aspects which makes it difficult to the elderly to adapt to the environment and make them more susceptible to pathologies (4).

This process inevitably causes some kind of disability during the twenty-two years of life expectancy after sixty years of age $(5,6)$. Also, it is known that one of the implacable functional alterations caused by aging, the sarcopenia, stands out from the others since it damages the musculoskeletal system and causes the decrease of anatomical and physiological parameters, specifically, the maximal muscle strength $(7,8,9,10)$.

Regarding sarcopenia range of effect, its general character is already known, affecting even the respiratory (11) muscles, as there is a strong inverse linear correlation between age and strength of these muscles (12). This specific involvement deserves more attention because it is directly associated with postoperative respiratory complications, as well as the deaths of elderly patients who underwent surgical procedures of thoraco-abdominal etiology $(13,14,15)$.

Still under an epidemiological context, being more specific to the city of Rio de Janeiro, the Datasus made public through CID-10, in 2011, between January and August, 1,941 elderly patients were hospitalized due to respiratory diseases and, of this total, 444 progressed to death (16). This fact makes it even more necessary to maintain the functionality of the respiratory muscles, since it is not only responsible for the mobilization of atmospheric air for serum homeostasis of $\mathrm{O}_{2}$ and $\mathrm{CO}_{2}$, but also for the bronchial hygiene which will minimize the risk of respiratory infections $(17,18,19,20)$, especially when such infection occurs in nosocomial environment, especially regarding pneumonia, which can represent $35.8 \%$ of total deaths from hospital infections by the elderly (21).

In the light of the current scientific production, it is solid to recognize the efficacy of different programs of exercise on respiratory muscle strength when they are prescribed specifically for it $(22,23,24,25,26)$. In a different way, the regular practice of various forms of physical activity which is widely recognized for its 
benefits, does not seem to have its effects related to the strength of respiratory muscles when not specifically targeted to them. This fact turns to be very relevant, considering that the stimulus to physical activity are interventions commonly recommended by health professionals such as doctors, nurses, physiotherapists and physical education teachers, though these benefits are sometimes estimated.

From the above, the present study aimed to systematically review the studies that have sought to compare the strength of respiratory muscles between sedentary and physically active old people in respiratory muscle nonspecific training programs.

\section{Materials and methods}

This research was conducted in the Stricto Sensu Postgraduate study program from the Sports and Exercise Sciences course at University Gama Filho, Rio de Janeiro, Brazil, from June 2011 to June 2012.

\section{Inclusion criteria}

Be an original scientific study, classified in its typology as descriptive, correlational, experimental or comparative causal; had been published between 2002 to 2012; have as a dependent variable the regular practice of physical activity which may be assisted or not, in its different forms as long as it's not specifically directed towards respiratory muscle training; have as variable dependent the strength of the respiratory muscles; have included in their sample physically active and sedentary groups $\geq 60$ years old of average age; have had no presence of subjects with any pathology in the sample; have a sample characterized by a physically active and a sedentary group or equivalent; have been clear in the samples and the different analysis performed.

\section{Search strategy}

We initially established the descriptors "atividade física", "músculos respiratórios" and "idoso", when in the vernacular and in English language, motor activity, respiratory muscles and elderly, available in DeCS and $\mathrm{MeSH}$, respectively, were used. In order to maximize the search their synonyms were adopted, as well as the related words used in pre-recovered scientific articles.

Then, respecting each data base operational differences when possible, we chose to search in primary fields "Title" or "Keywords" using "or" and "and" connectors and "Human" term as limit. The search was conducted into the following databases: LILACS, MEDLINE, COCHRANE, PEDro, SCIRUS and REDALYC.

\section{Selection criteria}

Developed by the Physiotherapy Evidence Database, the PEDro scale is a tool that quantifies the methodological quality of randomized controlled trials (RCTs, or "ensaios clínicos randomizados" - ECRs, in Portuguese) or quasi-randomized trials, demonstrating the external validity (criterion 1 , not counted), internal validity (criteria 2-9, counted) and if there are enough statistics for the results of these experiments to be interpreted (criteria 10 and 11, counted) $(27,28)$. In this way, the criteria that are recorded dichotomously as "SATISFIED" or "NOT SATISFIED" may show a maximum degree of methodological demand, reaching a 10-points total.

Adopting such scale as an instrument of selection for this systematic review, however, considering the almost total impossibility of blinding for the ones responsible for the intervention and for the subjects participating in the experiments conducted in the area of physical education, we chose the cutoff point as $\geq 5$ (29).

The PEDro scale was also used as a tool for the selection of non-experimental typology studies accepted in the inclusion criteria. However, these studies should necessarily meet criteria 1, 10 and 11, at least to legitimate their potential for generalization and interpretation of results $(27,28)$.

Preceding the selection itself, two of the authors found that the titles or summaries of available experiments complied with the inclusion criteria initially established. With this, it was possible to identify the experiments to be retrieved by each database. Then the authors sought to observe recurrence in more than one database, opting to retrieve them by their occurrence in the primary one. However, when there was the certain potential for data extraction, we chose to do it, minimizing the risk of losing an experiment and disadvantage a good future evidence-based practice (30). 
Finally, due to the cutoff point established for the selection criteria, an expert researcher for this specific matter retrieved and analyzed the experiments independently.

\section{Results}

Table 1 describes in four categories the quantity of studies identified into each data base as follows: "Available", for the articles corresponding to the preestablished descriptors in this review; "To retrieve", for the ones that might, possibly, meet the inclusion criteria; "Retrieved", for the works found in more than one databases, and which were retrieved from their first incidence the search sorting in the six selected databases; "Selected", regarding the ones that complied with all the inclusion criteria.

It is important to stress that not all the studies were classified as RCTs, but they complied entirely to the selection criteria specific to their typology, evidencing the legitimization of their generalization potential as well as their result interpretation $(27,28)$.

From the selection expressed in the Table 1, it is evident that the six selected experiments performed a total of sixteen comparisons of respiratory muscle strength between groups of physically active and sedentary old people. Of these comparisons, eleven showed that the first group had a statistically significant superiority of their referred muscle strength over the sedentary one.

However, this superiority presented by the physically active elderly did not guarantee respiratory muscle strength above the minimum value proposed for predictive normality, because, from the sixteen measurements, eleven were below the minimum value prediction (31). As for the groups of sedentary elderly, of the sixteen measurements, twelve were below this same predictive normality minimum value.

\section{Discussion}

According to the results in Table 2, which demonstrated, from the nine comparisons of MIP and seven of MEP performed, respectively, that numbers seven and four showed a statistically significant difference about the superiority of the physically active over the sedentary groups, it would be consistent to state that any regular physical activity might assure this superiority. Supporting this hypothesis, especially for their results, the studies of Cader et al. (32) and Summerhill et al. (33) obtained in all intergroup comparisons the statistically significant difference in favor of the physically active groups. However, this hypothesis loses strength since the systematic review also demonstrated that Watsford et al. (34) and Gonçalves et al. (35) did not identified a statistically significant superiority in at least one of their comparisons, specifically in MEP, and also Cader et al. (36) and Freitas et al. (37) in any of them.

An important point to consider is that the studies $(31,33,35)$ that showed statistically significant superiority in almost all comparisons between groups in favor of the physically active elderly people, did not describe in their methodologies the different types of physical activity that the elderly groups underwent, unlike the studies $(35,36,37)$ which

Table 1 - Data search results

\begin{tabular}{lcccc}
\hline Database & Available & To retrieve & Retrieved & Selected \\
\hline 1. LILACS & 43 & 4 & 4 & 2 \\
2. MEDLINE & 109 & 8 & 5 & 2 \\
3. COCHRANE & 547 & 2 & 0 & 0 \\
4. PEDro & 94 & 2 & 0 & 0 \\
5. SCIRUS & 397 & 4 & 2 & 1 \\
6. REDALYC & 73 & 2 & 1 & 1 \\
\hline TOTAL & 1263 & 22 & 12 & 6 \\
\hline
\end{tabular}

Source: Research data. 
failed to identify such superiority. This fact made it impossible to identify if some kind of activity could exert more efficient effect on respiratory muscle strength of these seniors.

But this line of reasoning is not possible for this systematic review, since Watsford et al. (34) described that the activities practiced were walking, cycling, tennis and squash, while Cader et al. (32) cited water aerobics, identifying the referred statistically significant superiority. These were very little different from Gonçalves et al. (35) which described walking, Cader et al. (36) that referred to water aerobics, and from Freitas et al. (37) which focused in swimming, running, walking, aerobics and cycling, and which failed to identify the referred superiority.

Still regarding a greater effectiveness for a given activity, in addition to the physical properties of water, the temperature (38) could be brought up as a factor that makes it more efficient than a non-aquatic physical activity. However, it would also be inadequate because the studies of Cader et al. $(32,36)$ that established water aerobics as the physical activity to their active groups identified a statistically significant superiority only in the second study. Confirming the discarding of the assumption brought up, Freitas et al. (37), which had swimmers in their sample also identified no significant difference between groups.

Thus, it appears that only one explanation becomes appropriate for the results expressed in the second table of this systematic review: the dosimetry, i.e., the ratio between volume and intensity, especially the periodization of physical activities, might have been a decisive factor for this result.

This attempt of explanation is justified by studies of Watsford et al. (34), Cader et al. (32) and Summerhill et al. (33) that adopted as an inclusion criterion in their experiments the requirement for at least three weekly training sessions. In this sense two selected studies stand out $(31,33)$ because, even if in a subjective way, they indicated the intensity, moderate or high, respectively, of the physical activities performed, and another study (32) mentioned the volume of sixty minutes in every training session.

In cooperation with the explanation of such superiority to have come from difference in prescription and periodization of physical activity, but unlike the previously mentioned authors, Gonçalves et al. (35) admitted that physically active elderly had the minimum weekly frequency of two sessions in their programs to be eligible for the experiment; Cader et al. (36), despite having described in their inclusion criterion the period of at least three months of regular water aerobics practice, did not indicated the minimum weekly frequency, volume and intensity of classes; and Freitas et al. (37), even though adopting the period of at least three times per week of attendance in the training program as an inclusion criterion, were flexible in allowing the volume of activities to be minimally thirty minutes and did not mention the intensity of the activity. From the identification of these methodological biases in the last three studies, one can attempt to explain why they have not presented in their results a statistically significant difference for all of the performed intergroup comparisons.

Henceforth we will discuss the results of the selected studies, shown in Table 2, about the strength of respiratory muscles presented, MIP and MEP, to the physically active as well as to sedentary elderly people, regarding the minimum predictive value of normality (31).

Table 2 - Selected studies Summary

(To be continued)

\begin{tabular}{|c|c|c|c|c|c|c|}
\hline Selected Study & $\begin{array}{c}\text { Group (n) } \\
\text { Age (Years) }\end{array}$ & Physical Activity / Period & $\begin{array}{c}\text { MIP } \\
\mathrm{cmH}_{2} \mathrm{O}\end{array}$ & $\begin{array}{c}\text { Inter } \\
\text { Group } \\
\text { p-value }\end{array}$ & $\begin{array}{l}\text { MEP } \\
\mathrm{CmH}_{2} \mathrm{O}\end{array}$ & $\begin{array}{c}\text { Inter } \\
\text { Group } \\
\text { p-value }\end{array}$ \\
\hline \multirow[t]{2}{*}{$\begin{array}{c}\text { Watsford et al. } \\
(34)\end{array}$} & $\begin{array}{c}\text { GMFAT }(n=18) \\
64.6 \pm 8.8\end{array}$ & $\begin{array}{l}\text { Walking, biking, running, } \\
\text { tennis and squash. } \\
\text { Minimum } 3 \text { weekly sessions } \\
\text { with moderate intensity and } \\
\text { non-defined volume. }\end{array}$ & $\begin{array}{c}-98.30 \pm \\
16.10 \downarrow\end{array}$ & $0.04^{*}$ & $\begin{array}{c}140.20 \pm \\
20.90 \uparrow\end{array}$ & $0.01^{*}$ \\
\hline & $\begin{array}{c}\text { GMS }(n=18) \\
65.2 \pm 8.7\end{array}$ & EIF & $\begin{array}{c}-86.30 \pm \\
18.30 \downarrow\end{array}$ & & $\begin{array}{c}112.20 \pm \\
35.40 \uparrow\end{array}$ & \\
\hline
\end{tabular}


Table 2 - Selected studies Summary

(To be continued)

\begin{tabular}{|c|c|c|c|c|c|c|}
\hline Selected Study & $\begin{array}{l}\text { Group (n) } \\
\text { Age (Years) }\end{array}$ & Physical Activity / Period & $\begin{array}{c}\mathrm{MIP} \\
\mathrm{CmH}_{2} \mathrm{O}\end{array}$ & $\begin{array}{l}\text { Inter } \\
\text { Group } \\
\text { p-value }\end{array}$ & $\begin{array}{l}\text { MEP } \\
\mathrm{CmH}_{2} \mathrm{O}\end{array}$ & $\begin{array}{l}\text { Inter } \\
\text { Group } \\
\text { p-value }\end{array}$ \\
\hline \multirow[t]{2}{*}{$\begin{array}{l}\text { Watsford et al. } \\
\text { (34) }\end{array}$} & $\begin{array}{l}\text { GFFAT }(n=18) \\
64.8 \pm 8.8\end{array}$ & $\begin{array}{l}\text { Walking, biking, running, } \\
\text { tennis and squash. } \\
\text { Minimum } 3 \text { weekly sessions } \\
\text { with moderate intensity and } \\
\text { non-defined volume. }\end{array}$ & $\begin{array}{c}-66.90 \pm \\
23.00 \downarrow\end{array}$ & \multirow[t]{2}{*}{$0.04^{*}$} & $\begin{array}{l}83.90 \pm \\
30.80 \uparrow\end{array}$ & \multirow[t]{2}{*}{ ÑS } \\
\hline & $\begin{array}{l}\text { GFS }(n=18) \\
65.2 \pm 10.3\end{array}$ & EIF & $\begin{array}{c}-52.30 \pm \\
19.00 \downarrow\end{array}$ & & $\begin{array}{l}68.70 \pm \\
26.70 \downarrow\end{array}$ & \\
\hline \multirow{6}{*}{$\begin{array}{c}\text { Gonçalves et al. } \\
(35)\end{array}$} & $\begin{array}{c}\text { GFA1 }(n=43) \\
65 \text { a } 69\end{array}$ & $\begin{array}{c}\text { Walking. } \\
\text { Minimum } 2 \text { weekly sessions } \\
\text { with non-defined intensity and } \\
\text { volume. }\end{array}$ & $\begin{array}{c}-56.28 \pm \\
23.25 \downarrow\end{array}$ & \multirow[t]{2}{*}{$0.0001^{*}$} & $\begin{array}{l}59.53 \pm \\
14.09 \downarrow\end{array}$ & \multirow[t]{2}{*}{0.1969} \\
\hline & $\begin{array}{c}\text { GC1 }(n=32) \\
65 \text { a } 69\end{array}$ & IF & $\begin{array}{c}-40.94 \pm \\
8.65 \downarrow\end{array}$ & & $\begin{array}{l}56.88 \pm \\
12.09 \downarrow\end{array}$ & \\
\hline & $\begin{array}{l}\text { GFA2 }(n=24) \\
\quad 70 \text { a } 74\end{array}$ & $\begin{array}{c}\text { Walking. } \\
\text { Minimum } 2 \text { weekly sessions } \\
\text { with non-defined intensity and } \\
\text { volume. }\end{array}$ & $\begin{array}{c}-49.58 \pm \\
16.93 \downarrow\end{array}$ & \multirow[t]{2}{*}{$0.004^{*}$} & $\begin{array}{l}62.92 \pm \\
14.81 \downarrow\end{array}$ & \multirow[t]{2}{*}{$0.01^{*}$} \\
\hline & $\begin{array}{c}\text { GC2 }(n=13) \\
70 \text { a } 74\end{array}$ & IF & $\begin{array}{c}-38.46 \pm \\
7.46 \downarrow \\
\end{array}$ & & $\begin{array}{c}50.77 \pm \\
14.83 \downarrow \\
\end{array}$ & \\
\hline & $\begin{array}{c}\text { GFA3 }(n=12) \\
75 \text { a } 79\end{array}$ & $\begin{array}{c}\text { Walking. } \\
\text { Minimum } 2 \text { weekly sessions } \\
\text { with non-defined intensity and } \\
\text { volume. }\end{array}$ & $\begin{array}{c}-47.27 \pm \\
16.96 \downarrow\end{array}$ & $0.02^{*}$ & $\begin{array}{l}61.25 \pm \\
15.54 \downarrow\end{array}$ & $0.01^{*}$ \\
\hline & $\begin{array}{c}\text { GC3 }(n=12) \\
75 \text { a } 79\end{array}$ & IF & $\begin{array}{c}-35.00 \pm \\
5.64 \downarrow \\
\end{array}$ & & $\begin{array}{c}47.50 \pm \\
10.97 \downarrow \\
\end{array}$ & \\
\hline \multirow[t]{2}{*}{ Cader et al. (36) } & $\begin{array}{c}\text { GHIDRO }(n=8) \\
65.0 \pm 2.43\end{array}$ & $\begin{array}{l}\text { Water aerobics } \\
\text { Periodization, volume and } \\
\text { intensity not defined. }\end{array}$ & $\begin{array}{c}-70.00 \pm \\
6.41 \downarrow\end{array}$ & \multirow[t]{2}{*}{0.11} & \multirow[t]{2}{*}{ ÑC } & \\
\hline & $\begin{array}{c}\text { GS }(n=8) \\
69.0 \pm 2.06\end{array}$ & IF & $\begin{array}{c}-53.13 \pm \\
6.33 \downarrow \\
\end{array}$ & & & \\
\hline \multirow[t]{2}{*}{$\begin{array}{l}\text { Cader et al. } \\
\text { (32) }\end{array}$} & $\begin{array}{l}\text { GHIDRO }(n=10) \\
\quad 63.2 \pm 2.5\end{array}$ & $\begin{array}{l}\text { Water aerobics } \\
\text { Minimum } 3 \text { weekly sessions } \\
\text { with } 60 \text {-minute volume and } \\
\text { intensity not defined. }\end{array}$ & $\begin{array}{c}-77.00 \pm \\
7.30 \downarrow\end{array}$ & \multirow[t]{2}{*}{$0.015^{\star}$} & \multirow[t]{2}{*}{$\tilde{N C}$} & \\
\hline & $\begin{array}{c}\text { GS }(n=10) \\
68.2 \pm 5.8\end{array}$ & IF & $\begin{array}{c}-51.50 \pm \\
19.40 \downarrow \\
\end{array}$ & & & \\
\hline \multirow[t]{2}{*}{$\begin{array}{l}\text { Summerhill } \\
\text { et al. (33) }\end{array}$} & $\begin{array}{c}\text { GFA }(n=12) \\
75.0 \pm 5.0\end{array}$ & $\begin{array}{l}\text { Cardiorespiratory activity, non- } \\
\text { defined endurance. } \\
\text { Minimum } 3 \text { weekly sessions } \\
\text { with volume } \geq 30 \text { minutes, } \\
\text { vigorous intensity. }\end{array}$ & $\begin{array}{l}-99.00 \pm \\
32.00 \uparrow\end{array}$ & \multirow[t]{2}{*}{$0.03^{*}$} & $\begin{array}{c}130.00 \pm \\
44.00 \uparrow\end{array}$ & \multirow[t]{2}{*}{$0.002^{*}$} \\
\hline & $\begin{array}{c}\text { GS }(n=12) \\
73.0 \pm 4.0\end{array}$ & EIF & $\begin{array}{c}-75.00 \pm \\
14.00 \uparrow\end{array}$ & & $\begin{array}{l}80.00 \pm \\
24.00 \uparrow\end{array}$ & \\
\hline $\begin{array}{l}\text { Freitas et al. } \\
\text { (37) }\end{array}$ & $\begin{array}{l}\text { CAFR }(n=35) \\
\quad \geq 60\end{array}$ & $\begin{array}{l}\text { Swimming, walking, running, } \\
\text { gymnastics and cycling. } \\
\text { Minimum } 3 \text { weekly sessions } \\
\text { with volume } \geq 30 \text { minutes } \\
\text { and non-defined intensity. }\end{array}$ & $\begin{array}{c}-66.90 \pm \\
21.10 \downarrow\end{array}$ & 0.99 & $\begin{array}{l}81.70 \pm \\
24.00 \uparrow\end{array}$ & 0.17 \\
\hline
\end{tabular}


Table 2 - Selected studies Summary

(Conclusion)

\begin{tabular}{ccccccc}
\hline Selected Study & $\begin{array}{c}\text { Group ( } \mathrm{n}) \\
\text { Age (Years) }\end{array}$ & Physical Activity / Period & $\begin{array}{c}\text { MIP } \\
\mathrm{CmH}_{2} \mathbf{O}\end{array}$ & $\begin{array}{c}\text { Inter } \\
\text { Group } \\
\mathbf{p} \text {-value }\end{array}$ & $\begin{array}{c}\text { MEP } \\
\mathrm{cmH}_{2} \mathrm{O}\end{array}$ & $\begin{array}{c}\text { Inter } \\
\text { Group } \\
\mathbf{p} \text {-value }\end{array}$ \\
\hline $\begin{array}{c}\text { Freitas et al. } \\
(37)\end{array}$ & $\begin{array}{c}\text { SAFR }(\mathrm{n}=26) \\
\geq 60\end{array}$ & EIF & $\begin{array}{c}-66.90 \pm \\
17.80 \downarrow\end{array}$ & 0.99 & $\begin{array}{c}73.90 \pm \\
19.40 \uparrow\end{array}$ & 0.17 \\
\hline
\end{tabular}

Note: GMFAT: Physically Active Male Group; GMS: Sedentary Male Group; GFFAT: Physically Active Female Group; GFS: Sedentary Female Group; EIF: Equivalent to physical inactivity; IF: physical inactivity; GFA1: Physically Active Group, first age group; GFA2: Physically Active Group, second age group; GFA3: Physically Active Group, third age group; GC1: Control Group, first age group; GC2: Control Group, second age group; GC3: Control Group, third age group; GFA: Physically Active Group; GS: Sedentary group; GHIDRO: Water aerobics group; CAFR: With regular physical activity; SAFR: With no regular physical activity; MIP: maximal inspiratory pressure; MEP: maximal expiratory pressure; * : statistically significant difference $(P<0.05)$; $\downarrow$ : value inferior to minimum normality predictive level; $\uparrow$ : value superior to minimum normality predictive level; ÑS: statistically non-significant difference; ÑC: Variable dependent not compared. Source: Research data.

It confirms that in the nine groups of physically active elderly who formed the samples of the six studies selected for this systematic review, nine measurements of inspiratory muscles and seven of expiratory were performed, totaling sixteen measurements of respiratory muscles, all demonstrated in the second table. Of these measurements, eleven showed the strength of respiratory muscles below the minimum predictive value of normality (31), specifically eight of the nine evaluations of MIP and three of the seven MEP. A plausible explanation for these findings would be the non-specificity provided for the referred muscle system in training programs that the physically active elderly were submitted.

Supporting this possibility, the experiment (39) investigated the chronic effects of two different exercise programs on the strength of respiratory muscles - one was held in aerobics classes and other in yoga lessons. The experiment intervention lasted twelve weeks and despite not having been carried out with a sample of seniors, but with adults with an average age between $27.8 \pm 9.0$ years old, the results showed a statistically significant difference $\mathrm{p}$-value $=$ 0.05 for males, when comparing the $\mathrm{cmH}_{2} \mathrm{O}$ absolute deltas of $2.8 \pm 13.8$ from aerobics versus $19.5 \pm 13.0$ $\mathrm{cmH} 20$ from yoga; and a $\mathrm{p}$-value $=0.01$ for females and a comparison of $3.9 \pm 6.5 \mathrm{cmH}_{2} \mathrm{O}$ from aerobics versus $20.0 \pm 13.9 \mathrm{cmH}_{2} \mathrm{O}$ from yoga training. With the findings of this experiment (39), the idea that an activity with greater specificity for the respiratory muscles, such as yoga, can generate significant effects is confirmed.

In this context, that effect might be objected, specifically on the respiratory muscles in the elderly, since the above experiment did not present in their sample the subject referred. However, the elderly, as any individual in different age groups, are likely to benefit from the positive effects of regular physical activity, especially when prescribed with a specific objective, a fact which is proved by one of the experiments (40) selected in this systematic review. This experiment, by submitting a group of elderly patients with an average age of $76.48 \pm 2.12$ years old with a protocol of inspiratory muscle training, demonstrated an evolution of $-31.67 \pm 11.11 \mathrm{cmH}_{2} \mathrm{O}$, presented in the diagnostic evaluation, to $-55.24 \pm$ 23:26 $\mathrm{cmH}_{2} \mathrm{O}$ in the cumulative one, and showing a $\mathrm{cmH}_{2} \mathrm{O}$ absolute delta of +23.57 and a p-value $=$ 0.0001 . This statistically significant result reinforces the hypothesis that the elderly are also subject to the benefits of regular physical activity and the respiratory muscles, as well as the peripheral ones, are also able to undergo physiological adaptations to the exercises. It should be clarified that the training of the muscles in this experiment was via the equipment Threshold - IMT (Respironics/USA - 2004), in which a load of gradual work was employed, starting at the value of $50 \%$ of maximal inspiratory pressure shown in the pre-intervention assessment, with subsequent increase of $10 \%$ per week until the fourth 
week, and 5\% from the fifth week until 100\% completion in eighth week, keeping this value until the last two weeks. The sessions lasted twenty minutes, with seven series of strengthening with two minutes each and a break for a minute recovery between sets, for ten weeks, and three sessions of training in the same microcycle.

Another issue especially observed in the groups of physically active seniors was that, from the sixteen comparisons with minimum predictive normality values (31), eleven were found below the prediction values: in eight of the nine comparisons of inspiratory muscles and in three of the seven comparisons of expiratory muscle system.

In this sense, acknowledging that none of the physical activity programs offered to seniors in the samples selected of this systematic review studies were specific to the respiratory muscle system, there seems to be two possibilities for this finding. The first is that the inspiratory muscles seem to be more resistant to the non-specific stimulation of the used programs, and it should also be more affected by the process of sarcopenia caused by aging; the second possibility is that the expiratory muscle system respond better to this non-specific stimulation, or it would be more resistive to the referred functional loss caused by the aging process.

Supporting the first explanation, studies $(31,32$, $35,36,37$ ) found that the physical activity programs offered to seniors failed to ensure that their muscle strength present more than minimal predictive value of normality (31). However, reviving a possibility contrary to these same studies, the experiment conducted by Summerhill et al. (33), since the physical activity offered was endurance with intensity classified as vigorous, was able to promote this benefit to the inspiratory muscles.

As for the muscles seeming to be most affected by the deleterious effects of aging, one of the experiments (41), researching the evolution of respiratory muscle strength in men and women in six age groups stratified in decades, beginning at twenty and ending at eighty-years-old, outlined the measures of respiratory muscle strength compared with the predicted values of normality (31) for each gender and all of the values of maximal inspiratory pressure measured in the sample were significantly lower than those of reference for both men and women, on a p-value $\leq$ 0.05 . However, there were no significant differences between the measured and predicted values for maximal expiratory pressure for men and women.

Regarding the possibility of the expiratory muscles respond better to such nonspecific stimuli, or that it would be more resistive to the functional loss by the aging process, it is relevant to ratify the findings of one study (41), which showed no statistically significant difference in any of surveyed age groups when compared the strength of expiratory muscles of their samples with the values proposed as normal (31). This result supports the possibility of the expiratory muscles resist more to the sarcopenia caused by aging. One should also pay attention to the data shown in Table 2 of this systematic review, which demonstrates that in three experiments $(31,33,37)$ all physically active groups showed higher strength on the expiratory muscles values than the normality predicted ones (31). This result, in particular for two selected studies (31, 33), may be due to the greater attention in prescribing and timing the physical activities that, although not specific to the referred muscles, could guarantee a minimum stimulation that generate the chronic physiological adaptations needed to the referred muscle system demonstrate its strength above the normality minimum predictive value (31).

As for the third mentioned study (37), their sample also showed values superior to the predictive, however, a consistent explanation for this fact is not possible because, as already mentioned above, its methodology did not present anything to justify their results. Also, it is important to mention that this same study identified no statistically significant difference in the comparison between the physically active and sedentary groups. Thus it appears that interventions of uncontrolled variables could come explain this result.

Regarding the results presented by the nine groups of sedentary elderly or equivalent who composed the samples of the selected studies and were subject of sixteen analysis of the respiratory muscles, of which nine of inspiratory and seven of expiratory muscles, all expressed in the table 2 , we observed that twelve measurements showed a statistically significant difference inferiority of the strength of respiratory muscles on the minimum predictive value of normality (31): eight of the nine MIP assessments and four of the seven MEP.

The first and perhaps most logical of the possibilities justifying these results is the very condition of 
the groups that were classified as sedentary. In this sense, the elderly in the sample from the studies by Gonçalves et al. (35) and Cader et al. (36) showed the strength of respiratory, inspiratory and expiratory muscles lower than the prediction levels. By understanding that the aging process when associated with physical inactivity makes the deleterious effects from this process potentiated, the above studies are justified by itself. Nevertheless, confirming them, there are still other experiments $(11,12)$ which investigated the strength of inspiratory and expiratory musculature in various age groups and concluded that such muscles suffer a shrink with the advancing of age, indicating a decrease in both muscle groups, in males and females. Complementing, other experiments $(42,43)$ have described that the functional loss, especially the strength of respiratory muscles actually becomes present with the advancing age and is much more perceived when physical inactivity is associated with the aging process.

It is relevant to note that some groups, although classified as sedentary or equivalent, showed some respiratory strength values higher than the normality predictive (31): the groups from the studies by Watsford et al. (34) and Freitas et al. (37) showed strength of expiratory muscles greater than normal predictive ones, as well as the ones from Summerhill et al. (33) whose inspiratory strength values were also over the predictive values. Therefore, according to these findings and the results from the experiment of Costa et al. (41) the possibility of the expiratory muscles to be less affected by senile sarcopenia is confirmed.

\section{Conclusion}

From the results and the discussion that guided this systematic review, we confirm that the functionality of the respiratory muscles is also susceptible to sarcopenia from senescence, and is worsened when associated with physical inactivity.

We conclude that the physical activity programs offered by the selected studies led the physically active elderly to have respiratory muscle strength statistically higher than the sedentary. Still, this strength was not necessarily higher than the normality minimum predictive value.

Therefore, it is suggested to the healthcare professionals a guidance routine to seniors about the need for joining physical activity programs, and to not ignore their health. Such guidelines should point out the benefits of this practice for lung capacity, and thereby improve their life quality. It is recommended also to doctors, nurses, physiotherapists and physical education teachers who work in training programs for the elderly, a greater attention to the fundamental principles of physical training, especially regarding the volume and intensity of the exercise offered and also its periodization. Because, in consequence of proper handling of these variables of physical training, even if the activities are not specifically designed to respiratory muscles, they can provide to that population the maintenance of the physical fitness components related to health at recommended levels, even if remotely, as well as the strength of inspiratory and expiratory muscles above the predictive values of normality.

On the relevance of the respiratory muscles in the context of problematization exposed in this systematic review, it would be appropriate that a specific respiratory muscle training was included in the training programs for the elderly, especially because it does not represent any additional cost, and therefore it can guarantee the maintenance of inspiratory and expiratory muscle strength levels above the normality predictive values.

\section{References}

1. Instituto Brasileiro de Geografia e Estatística - IBGE. Sinopse dos Resultados do Censo 2010. 2010 [cited 2011 Oct 3]. Available from: http://www.censo2010. ibge.gov.br/sinopse/webservice/

2. Horta ALM, Ferreira DCO, Zhao LM. Envelhecimento, estratégias de enfrentamento do idoso e repercussões na família. Rev Bras Enferm. 2010;63(4):523-8.

3. Tannure MC, Alves M, Sena RR, Chianca TCM. Perfil epidemiológico da população idosa de Belo Horizonte, MG, Brasil. Rev Bras Enferm. 2010;63(5):817-22.

4. Unicovsky MAR, Idoso com sarcopenia: uma abordagem do cuidado da enfermeira. Rev Bras Enferm. 2004;57(3):298-302.

5. Camargos MCS, Perpétuo IHO, Machado CJ. Expectativa de vida com incapacidade funcional em idosos em São Paulo, Brasil. Rev Panam Salud Publica. 2005;17(5-6):379-86. 
6. Alencar NA, de Souza JV Jr., Aragão JCB, Ferreira MA, Dantas EHM. Nível de atividade física, autonomia funcional e qualidade de vida em idosas ativas e sedentárias. Fisioter Mov. 2010;23(3):473-81.

7. Fanciulli G, Delitada A, Delitada G. Growth hormone, menopause and ageing: no definite evidence for 'rejuvenation' with growth hormone. Hum Reprod Update. 2009;15(3):341-58.

8. Goodpaster BH, Park SW, Harris TB, Kritchevsky SB, Nevitt M, Schwartz AV, et al. The loss of skeletal muscle strength, mass, and quality in older adults: the health, aging and body composition study. J Gerontol A Biol Sci Med Sci. 2006;61(10):1059-64.

9. Janssen I, Heymsfield SB, Ross R. Low relative skeletal muscle mass (sarcopenia) in older persons is associated with functional impairment and physical disability. J Am Geriatr Soc. 2002;50(5):889-96.

10. Pícoli TS, Figueiredo LL, Patrizzi LJ. Sarcopenia e envelhecimento. Fisioter Mov. 2011;24(3):455-62.

11. Simões RP, Castello V, Auad MA, Dionísio J, Mazzonetto M. Prevalence of reduced respiratory muscle strength in institutionalized elderly people. Sao Paulo Med J. 2009;127(2):78-83.

12. Simões LA, Dias JMD, Marinho KC, Pinto CLLR, Britto RR. Relationship between functional capacity assessed by walking test and respiratory and lower limb muscle function in community-dwelling elders. Rev Bras Fisioter. 2010;14(1):24-30.

13. Bellinetti LM, Thomson, JC. Avaliação muscular respiratória nas toracotomias e laparotomias superiores eletivas. J bras pneumol. 2006;32(2):99-105.

14. Neto LJ, Thomson JC, Cardoso JR. Complicações respiratórias no pós-operatório de cirurgias eletivas e de urgência e emergência em um hospital universitário. J bras pneumol. 2005;31(1):41-7.

15. Freitas FS, Parreira VF, Ibiapina CC. Aplicação clínica do pico de fluxo da tosse: uma revisão de literatura. Fisioter Mov. 2010;23(3):495-502.

16. Organização Panamericana da Saúde; Organização Mundial da Saúde. CID-10: classificação estatística internacional de doenças e problemas relacionados à saúde. 2008 [cited 2011 Oct 5]. Available from: http:// www.datasus.gov.br/prc/datasus.htm/
17. Suleman M, Abaza KT, Gornall C, Kinnear WJ, Willis JS, Mahajan RP. The effect of a mechanical glottis on peak expiratory flow rate and time to peak flow during a peak expiratory flow manoeuvre: a study in normal subjects and patients with motor neurone disease. Anaesthesia. 2004;59(9):872-5.

18. Salam A, Tilluckdharry L, Amoateng-Adjepong Y, Manthous CA. Neurologic status, cough, secretions and extubation outcomes. Intensive Care Med. 2004;30(7):1334-9.

19. Sivasothy P, Brown L, Smith IE, Shneerson, JM. Effect of manually assisted cough and mechanical insufflation on cough flow of normal subjects, patients with chronic obstructive pulmonary disease (COPD), and patients with respiratory muscle weakness. Thorax. 2001;56(6):438-44.

20. Ishii M. Benefit of forced expiratory technique for weak cough in a patient with bulbar onset Amyotrophic Lateral Sclerosis. J Phys Ther Sci. 2004;16:137-41.

21. Guimarães AC, Donalisio MR, Santiago THRI, Freire JB. Óbitos associados à infecção hospitalar, ocorridos em um hospital geral de Sumaré-SP, Brasil. Rev Bras Enferm. 2011; 64(5):864-9.

22. Ide MR, Belini MAV, Caromano FA. Effects of an aquatic versus non-aquatic respiratory exercise program on the respiratory muscle strength in healthy aged persons. Clinics. 2005;60(2):151-8.

23. Ide MR, Caromano FA, Dip MAVB, Guerino MR. Exercícios respiratórios na expansibilidade torácica de idosos: exercícios aquáticos e solo. Fisioter Mov. 2007;20(2):33-40.

24. Costa D, Toledo A, Silva AB, Sampaio LMM. Influence of noninvasive ventilation by BiPAP $^{\circledR}$ on exercise tolerance and respiratory muscle strength in chronic obstructive pulmonary disease patients (COPD). Rev Latino-Am Enfermagem. 2006;14(3):378-82.

25. Cader S, da Silva EB, Vale R, Bacelar S, Monteiro MD, Dantas E. Efeito do treino dos músculos inspiratórios sobre a pressão inspiratória máxima e a autonomia funcional de idosos asilados: Pimáx e autonomia funcional em idosos asilados. Motri. 2007;3(1):279-88.

26. Kim J, Davenport P, Sapienza C. Effect of expiratory muscle strength training on elderly cough function. Arch Gerontol Geriatr. 2009;48(3):361-6. 
27. Physiotherapy Evidence Database - PEDro. Sydney: The center for evidence-based physiotherapy [updated 2007 Oct 15; cited 2012 Apr 18]. Available from: www.pedro.org.au.

28. Shiwa SR, Costa LOP, Moser ADL, Aguiar IC, Oliveira LVF. PEDro: a base de dados de evidências em Fisioterapia. Fisioter Mov. 2011;24(3):523-33.

29. Coury HJCG, Moreira RFC, Dias NB. Efetividade do exercício físico em ambiente ocupacional para controle da dor cervical, lombar e do ombro: uma revisão sistemática. Rev bras fisioter. 2009;13(6):461-79.

30. Dias RC, Dias JMD. Prática baseada em evidências: uma metodologia para a boa prática fisioterapêutica. Fisioter Mov. 2006;19(1):11-6.

31. Neder JA, Andreoni S, Lerario MC, Nery LE. Reference values for lung function tests. II. Maximal respiratory pressures and voluntary ventilation. Braz J Med Biol Res. 1999;32(6):719-27.

32. Cader AS, Pereira FD, Vale RGS, Dantas EHM. Comparación de la fuerza de la musculatura inspiratória entre mujeres mayores sedentárias y practicantes hidrogimnasia. Rev esp geriatr gerontol. 2007;42(5):271-5.

33. Summerhill EM, Angov N, Garber C, McCool FD. Respiratory muscle strength in the physically active elderly. Lung. 2007;185(6):315-20.

34. Watsford ML, Murphy AJ, Pine MJ, Coutts AJ. The effect of habitual exercise on respiratory-muscle function in older adults. J Aging Phys Act. 2005;13(1):34-44.
35. Gonçalves MP, Tomaz CAB, Cassiminho ALF, Dutra MF. Avaliação da força muscular inspiratória e expiratória em idosas praticantes de atividade física e sedentárias. R bras Ci e Mov. 2006;14(1):37-44.

36. Cader AS, Vale RGS, Pereira FD, Dantas EHM. Comparação da PImáx e da qualidade de vida entre idosas sedentárias, asiladas e praticantes de hidroginástica. Fit Perform J. 2006;5(2):102-8.

37. Freitas FS, Ibiapina CC, Alvim CG, Britto RR, Parreira VP. Relação entre força de tosse e nível funcional em um grupo de idosos. Rev Bras Fisioter. 2010;14(6):470-6.

38. Fagundes AA, Silva RF. Efeitos da imersão em água aquecida sobre o sistema respiratório. Fisioter Mov. 2006;19(4):113-8.

39. Godoy DV, Bringhenti RL, Severa A, Gasper R, Poli LV. Ioga versus atividade aeróbia: efeitos sobre provas espirométricas e pressão inspiratória máxima. J bras pneumol. 2006;32(2):130-5.

40. Cader AS, Silva EB, Vale RS, Bacelar S, Monteiro MD, Dantas EHM. Efeito do treino dos músculos inspiratórios sobre a pressão inspiratória máxima e a autonomia funcional de idosos asilados. Motri. 2007; 3(1):279-88.

41. Costa D, Gonçalves HA, Lima LP, Ike D, Cancelliero KM, Montebelo MIL. Novos valores de referência para pressões respiratórias máximas na população brasileira. J. bras. pneumol. 2010;36(3):306-12.

42. Kamel HK. Sarcopenia and aging. Nutr Rev. 2003; 61(5):157-67.

43. Funes JAA, Mayo EJG. Benefícios de la práctica del ejercicio en los ancianos. Gac Med Mex. 2004;140(4): 431-4.

Received: 05/11/2013

Recebido: 11/05/2013

Approved: 11/07/2013

Aprovado: 07/11/2013 